\title{
INSEMINASI BUATAN MENGGUNAKAN PERSILANGAN SPERMA LIMOSIN DAN SIMENTAL MELALUI SINKRONISASI BIRAHI SUATU USAHA INTENSIFIKASI REPRODUKSI SAPI UNTUK PENINGKATAN PETERNAKAN SAPI RAKYAT DI KECAMATAN KEDUNGADEM KABUPATEN BOJONEGORO
}

\author{
ARTIFICIAL INSEMINATION USES LIMOUSINE AND SIMENTAL SPERM CROSSES \\ THROUGH PASSION SYNCHRONIZATION AN EFFORT TO CATTLE REPRODUCTION TO \\ INCREASE PEOPLE'S CATTLE FARMING IN KEDUNGADEM DISTRICT, BOJONEGORO REGENCY
}

\author{
Emy Koestanti Sabdoningrum \\ Fakultas Kedokteran Hewan
}

\author{
Sunaryo Hadi Warsito \\ Fakultas Kedokteran Hewan \\ Heru Pramono \\ Fakultas Kedokteran Hewan
}

Siti Eliana

Fakultas Kedokteran Hewan

\begin{abstract}
ABSTRAK
Usaha peternakan sapi potong di desa Kedungrejo Kecamatan Kedungadem Kabupaten Bojonegoro pada umumnya belum menerapkan konsep usaha yang efisien mengingat banyak potensi dan peluang yang belum dimanfaatkan dan dikelola secara optimal terutama yang terkait reproduksi ternak dan produksi ternak sapi potong. Kendala yang sering dijumpai adalah rendahnya tingkat keberhasilan Inseminasi Buatan (IB) ternak sapi potong karena kualitas semen yang kurang baik dan skill inseminator belum memadai. Kondisi demikian juga merupakan gambaran dari Peternak Sapi Potong Desa Kedungrejo Kecamatan Kedungadem Kabupaten Bojonegoro. Desa Kedungrejo dipilih menjadi tempat pengembangan ternak sapi di lahan kering karena mempunyai potensi untuk pemuliabiakan persilangan sapi Lemosin dan sapi Simental yang menghasilkan daging yang bagus. Pengembangan ternak sapi di desa Kedungrejo Kecamatan Kedungadem bertujuan meningkatkan kegiatan perekonomian dalam mendukung usaha intensifikasi reproduksi sapi untuk peningkatan peternakan sapi rakyat. Kegiatan kepada masyarakat ini bertujuan pemenuhan swasembada daging melalui pengenalan, penyebarluasan, alih teknologi reproduksi dengan cara Inseminasi buatan menggunakan persilangan sperma Limousin dan Simental. Peternak sapi potong Desa Kedungrejo Kecamatan Kedungadem Bojonegoro mempunyai prospek peternakan sapi potong yang dapat dikembangkan untuk memenuhi swasembada daging yang sedang digalakkan. Target khusus luaran yang ingin dicapai berupa keberhasilan inseminasi, peningkatan angka kelahiran, perbaikan mutu genetik sapi potong melalui Inseminasi Buatan menggunakan persilangan sperma Limousin dan Simental di wilayah Desa Kedungrejo Kecamatan Kedungadem Bojonegoro.

Metode yang dipakai dalam pencapaian tujuan tersebut dengan sosialisasi Inseminasi Buatan menggunakan Persilangan Sperma Limousin dan Simental. Solusi yang ditawarkan adalah melalui tahap pembinaan, pelatihan dan aplikasi. Hasil kegiatan pengabdian kepada masyarakat ini menunjukkan bahwa Inseminasi Buatan menggunakan Persilangan Sperma Limousin dan Simental mempunyai prospek untuk dikembangkan sebagai peingkatan keberhasilan inseminasi, peningkatan angka kelahiran, perbaikan mutu genetik memberi pengaruh positif terhadap reproduktivitas sapi potong dan pemenuhan swasembada daging.
\end{abstract}

Kata kunci: Inseminasi Buatan, Persilangan Sperma Limosin dan Simental, sapi potong, Desa Kedungrejo Kecamatan Kedungadem Bojonegoro. 


\begin{abstract}
The beef cattle breeding business in Kedungrejo village, Kedungadem sub-district, Bojonegoro Regency in general has not implemented an efficient business concept considering that there are many potentials and opportunities that have not been utilized and managed optimally, especially those related to livestock reproduction and beef cattle production. Constraints that are often encountered are the low success rate of Artificial Insemination (IB) of beef cattle because poor quality cement and inseminator skills are not sufficient. Such conditions are also an illustration of the Beef Cattle Breeders in Kedungrejo Village, Kedungadem District, Bojonegoro Regency. Kedungrejo village was chosen to be a place for cattle development on dry land because it has the potential to breed cattle crosses of Lemosin and Simental cattle which produce good meat. The development of cattle in Kedungrejo village, Kedungadem sub-district, aims to increase economic activities in support of cattle reproduction intensification efforts to increase people's cattle farming. This activity for the community aims to fulfill meat self-sufficiency through the introduction, dissemination, transfer of reproductive technology by artificial insemination using Limousine and Simental sperm crosses. Beef cattle farmers in Kedungrejo Village Kedungadem Bojonegoro Subdistrict have the prospect of beef cattle breeding which can be developed to fulfill meat self-sufficiency that is being promoted. Specific targets of outcomes to be achieved include the success of insemination, increased birth rate, improvement of genetic quality of beef cattle through Artificial Insemination using Limousine and Simental sperm crosses in the Kedungrejo Village, Kedungadem Bojonegoro District. The method used in achieving this goal by socializing Artificial Insemination using Limousine and Simental Sperm Crosses. The solution offered is through the coaching, training and application stages. The results of community service activities indicate that Artificial Insemination using Limousine and Simental Sperm Crosses has the prospect of being developed as an increase in the success of insemination, increased birth rate, genetic quality improvement has a positive influence on beef reproductive and meat self-sufficiency.
\end{abstract}

Keywords: Artificial Insemination, Limousine and Simental Sperm Crosses, beef cattle, Kedungrejo Village Kedungadem Bojonegoro District

\section{PENDAHULUAN}

Universitas Airlangga, sebagai salah satu Perguruan Tinggi Negeri di Surabaya merupakan bagian dari masyarakat, yang turut bertanggung jawab terhadap berbagai persoalan di masyarakat. Sebagai bagian dari masyarakat, mahasiswa Universitas Airlangga memiliki tanggung jawab moral untuk menanggulangi kemiskinan dan segala permasalahan sosial serta memajukan pembangunan bangsa. Sebagai bentuk academic social responsibility, Universitas Airlangga sebagai suatu institusi pendidikan memiliki program Kuliah Kerja Nyata - Belajar Bersama Masyarakat atau yang lebih sering dikenal dengan KKN-BBM merupakan salah satu bentuk program pendidikan yang didasari oleh pemikiran bahwa mahasiswa adalah agen pembangunan yang juga harus dapat bekerja untuk memecahkan masalah-masalah pembangunan yang ada dalam kehidupan masyarakat. Secara nyata turut membantu memecahkan masalah masyarakat berdasarkan kompetensi bidang keilmuan masing-masing peserta KKN-BBM. Kompetensi ini disesuaikan dengan situasi, kondisi, masalah, dan prioritas kebutuhan masyarakat di lapangan dengan pendekatan ilmiah dan interdisipliner.

Desa Kedungrejo Kecamatan Kedungadem Kabupaten Bojonegoro. Survei yang telah dilaksanakan pada 16 Juni 2017 mendapatkan hasil yang tercantum sebagai berikut: Jumlah penduduk (L) 1512 jiwa, (P) 1637 jiwa, total: 3149 jiwa. Jumlah KK : 1130 KK. Rata-rata per KK: 3 orang. Mata Pencaharian : Petani dan Peternak sapi potong. Potensi Desa: Padi, tembakau, dan jagung serta sapi potong. Bila dilihat dari segi geografis, mata pencarian penduduk, populasi ternak dan daya dukung alam berupa pertanian maka daerah Desa
Kedungrejo Kecamatan Kedungadem Kabupaten Bojonegoro berpotensi baik untuk pengembangan ternak pada umumnya dan ternak sapi potong pada khususnya.

Saat ini pengembangan sapi potong sebagai salah satu komoditas unggulan sub sektor peternakan yang perlu mendapat perhatian serius, mengingat permintaan akan protein hewani baik daging, telur dan susu belum semuanya dapat dipenuhi oleh produksi dalam negeri. Untuk memenuhi kekurangan tersebut secara nasional, pemerintah mengimpor daging, susu maupun sapi dari luar negeri. Daya dukung keberhasilan pemuliabiakan sapi potong sangat kurang karena rendahnya mutu genetik dan rendahnya skill peternak dan inseminator dalam pemilihan bibit dan reproduksi sapi potong. Upaya untuk mengatasi tersebut diatas dipandang perlu untuk menambah pengetahuan petani peternak melalui pembinaan dan penyuluhan tentang cara pemilihan bibit sapi potong limousin dan simental yang menghasilkan daging yang tinggi dengan masa pemeliharaan yang pendek, cara inseminasi yang benar dengan disertai penyerentakan birahi sehingga meningkatkan keberhasilan inseminasi buatan.

Salah satu yang dapat ditempuh untuk meningkatkan produksi daging dan anak sapi atau pedet adalah dengan meningkatkan jumlah pemilikan sapi potong dan mutu genetik ternak. Hal ini dapat dilaksanakan dengan menerapkan Inseminasi Buatan (IB) pada sapi potong, karena semen yang digunakan terhadap IB berasal dari sapi jantan yang genetiknya baik dan angka Service Per Conception yang rata-rata lebih kecil Dengan demikian IB perlu ditingkatkan melalui upaya-upaya yang intensif, kontinyu dan berkesinambungan dengan penekanan pada 
aspek peningkatan mutu dan perluasan jangkauan pelayanan IB dalam bentuk satuan pelayanan inseminasi buatan (SPIB) dengan mewujudkan pelayanan IB yang prima dan memasyarakat.

Menurut Bandini (2004), Inseminasi Buatan adalah pemasukan atau penyampaian semen ke dalam saluran kelamin betina dengan menggunakan alat-alat buatan manusia. Dalam praktek prosedur IB tidak hanya meliputi deposisi atau penyampaian semen ke dalam saluran kelamin betina, tetapi juga tak lain mencakup seleksi dan pemeliharaan pejantan, penampungan, penilaian, pengenceran, penyimpanan atau pengangkutan semen, Inseminasi, pencatatan dan juga penentuan hasil inseminasi pada hewan betina, bimbingan dan penyuluhan pada ternak. Menurut Ihsan (1993), keuntungan IB yaitu Daya guna seekor pejantan yang genetik unggul dapat dimanfaatkan semaksimal mungkin. Terutama bagi peternak-peternak kecil seperti umumnya ditemukan di Indonesia program IB sangat menghemat biaya di samping dapat menghindari bahaya dan juga menghemat tenaga pemeliharaan pejantan yang belum tentu merupakan pejantan terbaik untuk diternakkan. Pejantan-pejantan yang dipakai dalam IB telah diseleksi secara teliti dan ilmiah dari hasil perkawinan betina-betina unggul dengan pejantan unggul pula. Calving Interval dapat diperpendek dan terjadi penurunan jumlah betina yang kawin berulang. Dapat mencegah penularan penyakit menular akibat kawin alam. Persilangan limousin dan simental mempunyai keunggulan. Jenis Ras dan bentuk tubuh. Sejati nya semua jenis ras punya kelebihan dan kekurangan masing-masing. Tentang hal ini sudah banyak diulas di pelbagai literatur tentang sapi potong. Hanya kita sebagai Praktisi peternakan seyogyanya perlu memperhatikan nilai-nilai praktis dan ekonomis dari jenis ras tersebut baik dari sisi kekuatan finansial peternak, peruntukannya dan timing tepat penjualannya. Seperti kita ketahui, untuk ADG (penambahan berat harian) bolehlah diakui memang sapi jenis limousin dan simental F1 telah menjadi primadona yang mana ADG nya mampu mencapai $1,3-2 \mathrm{~kg} /$ harinya. Disusul di belakangnya silangan SIMPO dan LIMPO dengan ADG 1-1,7kg/hari. Berlanjut kemudian PO murni, Bali dan seterusnya yang lebih rendah penambahan berat harian nya dan struktur tubuhnya. Namun poin terpenting untuk tidak kita lupakan dari semua itu tentunya adalah Fisiologi dan kriteria performance sapi itu sendiri. Tampilan fisik yang ideal mencakup body frame, power depan dan belakang sapi akan memengaruhi ADG, kemudahan pemeliharaan, dan harga purna jualnya.2.Umur dan berat badan. Usia sapi yang ideal untuk digemukkan adalah mulai 1,5 sampai dengan 2,5 tahun. di sini kondisi sapi sudah mulai maksimal pertumbuhan tulangnya dan tinggal mengejar penambahan massa otot (daging) yang secara praktis dapat dilihat dari gigi yang sudah berganti besar 2 dan 4 buah. Sapi yang sudah berganti
6 gigi besarnya (3 tahun ke atas) juga cukup bagus. Hanya di usia ini sudah muncul gejala fat (perlemakan) yang tentunya akan berpengaruh dengan nilai jual dari pelaku pemotongan ternak. Sapi apabila masih di bawah usia ideal penggemukan biasanya lebih lambat proses gemuknya dikarenakan selain bersamaan pertumbuhan tulang dan daging juga sangat rentan risiko penyusutan serta labil proses penambahan berat disebabkan adaptasi tempat yang baru, pergantian pola pakan dan teknis perawatan serta penyakit. Tentang variabel berat tubuh, pastinya akan kita lihat dulu dari jenis ras apa sapi yang akan kita pelihara. Sapi jenis limousin dan simmental maupun silangannya dengan PO kala umur 1,5 tahun sudah berbobot rata-rata $350-400 \mathrm{~kg}$, sedang sapi PO murni hanya kisaran 185-275 kg. Nah, dari sini nantinya kita akan mulai berhitung tentang teknis penilaian ideal untuk mengukur sistem pemeliharaan dan transaksi jual beli. 3. Masa pemeliharaan. Sesuai pengalaman kami yang baru sedikit ini, kami menyarankan pada mitra peternak kami bahwa sapi yang akan digemukkan agar memakai mekanisme: apabila masa panen jangka pendek (k. 1.100 hari) pilihlah jenis limousin, simental dan silangannya (F1 maupun F2) dengan berat mulai 390-500 kg. Jika proporsional pemeliharaannya, sapi tersebut akan mampu bertambah minimal $100 \mathrm{~kg}$ saat panennya. Namun kalau yang diinginkan masa panen jangka menegah dan panjang (k.1 250 hari hingga lebih dari 1 tahun) disarankan agar memilih jenis F1 simmental dan limousin yang murni genetiknya dengan berat di bawah $350 \mathrm{~kg}$. Kebanyakan peternak yang berpola seperti ini biasanya untuk investasi, pemurnian genetik indukannya.

\section{METODE PELAKSANAAN}

\section{Permasalahan Mitra}

Secara umum permasalahan peternakan sapi potong yang ditemui di desa Kedungrejo Kecamatan Kedung adem Bojonegoro adalah:

1. Produktivitas dan reproduktivitas ternak sapi potong menurun akibat ketidakberhasilan inseminasi buatan

2. Bibit sapi yang dihasilkan berupa sapi potong peranakan ongole yang relative pertumbuhannya lama dan perolehan dagingnya sedikit dengan tulang yang besar

3. Peternak kurang mengenali waktu dilakukan inseminasi buatan yang tepat

4. Inseminator kurang pengetahuan dalam pemeriksaan kebuntingan

5. Peternak kurang memiliki pengetahuan tentang Manajemen pemeliharaan dan reproduksi yang baik

Solusi yang ditawarkan berupa penerapan Inseminasi Buatan menggunakan Persilangan Sperma Limousin dan Simental melalui Sinkronisasi Birahi Suatu Usaha Intensifikasi 
Reproduksi Sapi untuk Peningkatan Peternakan Sapi Rakyat di Kecamatan Kedung adem Kabupaten Bojonegoro.

Metode pendekatan yang digunakan dalam pelaksanaan kegiatan pengabdian kepada masyarakat ini dilakukan dalam tiga tahap kegiatan meliputi:

I. Tahap Pembinaan:

a. Penyuluhan reproduksi sapi potong. Adapun materi pembinaan yang disampaikan meliputi: tanda-tanda birahi, waktu yang tepat untuk melakukan inseminasi buatan dan penyakit reproduksi

b. Penyuluhan tentang pemilihan bibit sapi potong. Meliputi: pengenalan breed sapi potong, keunggulan sapi limousin dan simental

c. Penyuluhan manajemen reproduksi dan pemeliharaan sapi potong. Meliputi: Keuntungan dan kerugian inseminasi buatan, pemeriksaan kebuntingan, pemberian pakan dan sanitasi kandang.

II. Tahap Pelatihan

Dalam upaya untuk meningkatkan keterampilan dan pengetahuan peternak dan masyarakat kecamatan Kedung adem mengenai reproduksi dan pemilihan bibit sapi potong yang baik dengan inseminasi buatan menggunakan sperma limousin dan simental melalui penyerentakan birahi maka akan dilakukan demo serta pelatihan:

1. Penyerentakan birahi dan inseminasi buatan dengan menggunakan sperma limousin dan simental.

2. Penerapan manajemen reproduksi dan pemeliharaan sapi potong yang baik.

III. Tahap Evaluasi

- Mencatat hasil inseminasi buatan sapi potong dari beberapa parameter yang diamati antara lain adalah Calving interval, Gestation Period, keberhasilan inseminasi buatan ditandai dengan kebuntingan dan kelahiran yang normal dan sehat.

- Memantau pengembangan dari keterampilan yang telah diberikan.

\section{HASIL DAN PEMBAHASAN}

1. Pelaksanaan program Pengabdian pada Masyarakat oleh Tim Pengemas Unair melakukan koordinasi yaitu persiapan untuk survey lokasi di Kecamatan Kedung adem Kabupaten Bojonegoro. Sebagai khalayak sasaran adalah Peternak Sapi Potong Desa Kedungrejo Kecamatan Kedung adem Kabupaten Bojonegoro untuk menentukan prioritas pemecahan masalah di daerah tersebut.

2. Tahap selanjutnya dilakukan koordinasi antara Peternak Sapi Potong Desa Kedungrejo Kecamatan Kedungadem Kabupaten Bojonegoro dan Kepala Desa Kedungrejo dengan Tim Pengabdian Kepada Masyarakat Universitas Airlangga untuk menentukan jadwal kegiatan.
3. Penentuan jadwal kegiatan di wilayah tersebut:

a. Identifikasi masalah reproduksi sapi potong dan inseminasi buatan sapi potong.

b. Pemberian questionnaire untuk mengetahui kemampuan peternak tentang reproduksi dan inseminasi buatan sapi potong.

c. Penyuluhan dan demo. Adapun materi-materi yang diberikan kepada para peternak yang meliputi:

- Penyuluhan reproduksi dan kasus gangguan reproduksi, cara pencatatan data (recording) dan diskusi penanganan reproduksi sapi potong.

Teknik Pengabdian Kepada Masyarakat akan melakukan transfer teknologi tepat guna dalam mengatasi permasalahan tersebut antara lain :

a. mendeteksi birahi,

b. penanganan gangguan reproduksi dan kasus-kasus penyakit yang sering terjadi pada sapi potong didaerah tersebut.

c. Inseminasi Buatan menggunakan Persilangan Sperma Limousin dan Simental melalui Sinkronisasi Birahi

Peternak sapi potong di Desa Kedungrejo Kecamatan Kedung adem Kabupaten Bojonegoro, masih minim pengetahuannya tentang reproduksi sapi potong dan sinkronisasi birahi serta pemilihan bibit sapi potong yang baik Setelah dilakukan penyuluhan dan praktek tentang inseminasi buatan menggunakan persilangan sperma Limousin dan Simental melalui sinkronisasi birahi menunjukkan respons yang positif yang berarti terjadi peningkatan pengetahuan peternak tentang manfaat inseminasi buatan menggunakan persilangan sperma Limousin dan Simental melalui sinkronisasi birahi. Pada kegiatan ini perangkat desa juga ikut terlibat, sehingga sangat mendukung kegiatan pengabdian kepada masyarakat, dan diharapkan pengetahuan ini dapat disebarluaskan ke wilayah sekitarnya. Respons kemampuan peternak dalam inseminasi buatan menggunakan persilangan sperma Limousin dan Simental melalui sinkronisasi birahi merupakan upaya dalam meningkatkan reproduksi dan produktivitas sapi potong yang memberi hasil yang positif.

Usaha peternakan di Desa Kedungrejo Kecamatan Kedung adem Kabupaten Bojonegoro sampai saat ini masih menghadapi banyak kendala, yang mengakibatkan produktivitas ternak masih rendah, salah satu kendala tersebut adalah masih banyak kasus gangguan reproduksi pada ternak betina, keberhasilan peternakan sebagian besar tergantung pada keberhasilan reproduksi. Betapa pentingnya proses reproduksi bagi usaha peternakan bila mengingat bahwa tanpa adanya reproduksi, mustahil produksi ternak dapat diharapkan mencapai maksimal. Oleh karena itu, pengelolaan reproduksi merupakan bagian yang amat penting dalam suatu usaha peternakan. Tujuan dari pengelolaan reproduksi yang baik pada ternak, adalah untuk memperoleh produksi ternak yang sebanyak-banyaknya sehingga diperoleh keuntungan yang 
Tabel 2. Hasil Questionnaire Peternak

\begin{tabular}{|c|c|c|c|}
\hline No. & Indikator & Sebelum PPM & Sesudah PPM \\
\hline 1. & Pengenalan tanda-tanda birahi sapi potong & $60 \%$ & $90 \%$ \\
\hline 2. & Pengetahuan gangguan kasus reproduksi sapi potong & $60 \%$ & $80 \%$ \\
\hline 3. & Pengetahuan penyerentakan birahi sapi potong & $30 \%$ & $75 \%$ \\
\hline 4. & Pengetahuan manfaat inseminasi buatan pada sapi potong & $70 \%$ & $95 \%$ \\
\hline 5. & Kemampuan pemilihan bibit sapi potong & $30 \%$ & $80 \%$ \\
\hline 6. & Keinginan melakukan penyerentakan birahi pada sapi potong & $30 \%$ & $95 \%$ \\
\hline 7. & $\begin{array}{l}\text { Keinginan inseminasi buatan menggunakan persilangan sperma Limousin dan } \\
\text { Simental pada sapi potong }\end{array}$ & $35 \%$ & $85 \%$ \\
\hline 8. & $\begin{array}{l}\text { Keberhasilan inseminasi buatan menggunakan persilangan sperma Limousin } \\
\text { dan Simental melalui penyerentakan birahi pada sapi potong }\end{array}$ & $40 \%$ & $85 \%$ \\
\hline
\end{tabular}

setinggi-tingginya bagi peternak. Efisiensi reproduksi pada sapi dianggap baik bila angka kebuntingan dapat mencapai 65-75\%; jarak antar melahirkan tidak melebihi 12 bulan atau 365 hari; waktu melahirkan sampai terjadinya kebuntingan kembali 60-90 hari; Angka perkawinan per kebuntingan 1,65 dan angka kelahiran 45-65\% (Hardjopranjoto 1995). Peternakan di Desa Kedungrejo Kecamatan Kedungadem Kabupaten Bojonegoro angka kebuntingan mencapai 40-50\%; jarak antar melahirkan melebihi 12 bulan atau 365 hari; waktu melahirkan sampai terjadinya kebuntingan kembali lebih dari 90 hari; dan angka kelahiran 40-50\%. Setelah dilakukan kegiatan pengabdian pada masyarakat Universitas Airlangga keberhasilan inseminasi buatan yang sebelumnya $40 \%$ menjadi $85 \%$. Kasus gangguan reproduksi sudah merupakan hal yang umum terjadi pada semua peternakan dimanapun peternakan itu berada, walaupun telah dilakukan penanggulangan dengan teknik yang mutakhir seperti halnya di negara-negara yang telah maju. Faktor-faktor yang memengaruhi proses reproduksi, ada beberapa ukuran yang dipakai untuk menyatakan adanya gangguan reproduksi tersebut yaitu: Jarak antar melahirkan melebihi 400 hari, jarak antar melahirkan sampai bunting kembali melebihi 120 hari, angka kebuntingan kurang dari $50 \%$, rata-rata jumlah perkawinan per kebuntingan lebih besar dari dua, jumlah induk sapi yang membutuhkan lebih dari tiga kali IB untuk terjadinya kebuntingan melebihi 30\%. Jika hal tersebut terjadi di dalam suatu kawasan peternakan, maka keadaan ini akan diikuti oleh menurunnya angka kelahiran dan produktivitas ternak, dan ini merupakan kerugian bagi peternak. Keadaan ini terjadi di Desa Kedungrejo Kecamatan Kedung adem Kabupaten Bojonegoro sebelum dilakukan kegiatan pengabdian pada masyarakat Universitas Airlangga. Bagi peternak sapi, kebuntingan adalah keuntungan namun bila terjadi kelainan atau gangguan reproduksi maka dapat memberikan kerugian yang cukup besar, secara ekonomis masalah kesehatan reproduksi sapi merupakan masalah besar bagi peternak, kasus-kasus gangguan reproduksi sangat dekat dengan kerugian ekonomi, oleh karena itu sangat perlu diadakan pencegahan, penanggulangan dan pengelolaan terhadap hal tersebut sehingga peternak terhindar dari kerugian yang berkelanjutan.

Dalam menanggulangi suatu kasus gangguan reproduksi pada ternak khususnya sapi, usaha yang perlu digalakkan adalah melaksanakan program kesehatan reproduksi. Makin tinggi daya reproduksi, makin tinggi pula populasi, produksi dan produktivitas ternak tersebut, sebaliknya jika daya reproduksi rendah karena adanya Kemajiran sehingga mengakibatkan menurunnya populasi, produksi dan produktivitasnya. Pada hakikatnya produksi di bidang peternakan hanya dapat diperoleh bila ada proses reproduksi. Daya reproduksi kelompok-kelompok ternak yang tinggi disertai dengan pengelolaan ternak yang baik akan menghasilkan efisiensi reproduksi yang tinggi diikuti dengan populasi, produksi dan produktivitas yang tinggi pula. Manfaat teknologi inseminasi buatan antara lain :

1. Perbaikan mutu genetik ternak

2. Mempercepat peningkatan populasi

3. Berpotensi untuk mencegah penularan penyakit kelamin yang ditularkan melalui saluran kelamin.

4. Mudah menentukan derajat kemurnian genetik

5. Dapat mengubah pola proses musim kawin yang serentak sesuai dengan kondisi lingkungan pada masing-masing lokasi peternakan.

6. Memudahkan petugas dalam pelayanan inseminasi karena adanya musim kawin dan kelahiran pedet terjadwal

Keberhasilan program inseminasi buatan sangat dipengaruhi oleh kondisi induk ternak sapi akseptor (sapi induk betina yang akan di IB) inseminasi, kualitas spermatozoa pada strow yang akan digunakan, keterampilan inseminator dan ketepatan deteksi birahi oleh pemilik/ pemelihara ternak betina/akseptor.

\section{Penyerentakan birahi}

Penyerentakan birahi atau sinkronisasi birahi adalah usaha yang bertujuan untuk mensinkronkan kondisi ternak 
berada dalam keadaan birahi. Sinkronisasi birahi pada umumnya menggunakan hormon Gonadotropin yaitu hormon progstaglandin F2 $\alpha$ (PGF2 $\alpha$ ) dengan prosedur yang telah ditetapkan. Perlakuan penyerentakan birahi dimaksudkan adalah untuk membuat satu musim kawin dalam jumlah banyak dan diharapkan kelahiran anak atau pedet dalam waktu bersamaan dalam jumlah banyak. Disamping itu penyerentakan birahi bertujuan untuk memudahkan pelaksanaan program inseminasi buatan terjadwal semusim yang disesuaikan dengan kondisi lingkungan yaitu kesiapan penyediaan pakan ternak atau hijauan makanan ternak. Induk akseptor inseminasi buatan terjadwal yang kondisi ovariumnya memiliki adanya korpus luteum (CL) maka induk tersebut cukup diberi suntikan hormon prastaglandin F2 $\alpha$ dosis tunggal saja. Induk calon akseptor akan timbul birahi 48 sampai 96 jam setelah pelaksanaan perlakukan penyuntikan hormon. Namun bagi induk akseptor tidak memperhatikan adanya CL pada ovariummya, maka umumnya diberikan 2 kali penyuntikan hormon progstaglandin F2 $\alpha$ dengan selang waktu 11-12 hari dari jarak waktu penyuntikan hormon pertama.

\section{Pengamatan birahi}

Pengamatan birahi terhadap induk calon akseptor terjadwal mulai dilakukan pada hari ke dua yaitu setelah 30 jam penyuntikan hormon prastaglandin F2 $\alpha$. Sebaiknya ternak dikandangkan agar pengamatan mudah dilakukan peternak (pemilik atau pemelihara ternak) sehingga diperoleh kondisi birahi awal, tengah, dan akhir. Waktu pengamatan yang sebaiknya dilakukan peternak adalah pagi pada jam 06.00- 07.00 WIB, siang hari pada jam 12.00-13.00 WIB dan pada malam hari pada jam 20.00-21.00 WIB. Lama pengamatan yang diperlukan peternak untuk mengetahui apakah ternak telah birahi atau belum berkisar antara kurun waktu 10-15 menit per waktu pengamatan. Inseminasi buatan dilaksanakan terhadap induk akseptor yang menunjukkan kondisi birahi setelah perlakuan sinkronisasi dengan hormon prostaglandin F2 $\alpha$. Inseminasi buatan yang terbaik dilaksanakan adalah setelah lama birahi nya di atas jam ke 9 dan di bawah jam ke 20 lama birahi induk sapi.

\section{DAFTAR PUSTAKA}

Aryogi, U., Umiyasih, D.B. Wijono dan D. Wahyono. 2000. Pengkajian rakitan teknologi penggemukan sapi potong. Pros. Seminar Hasil Penelitian/Pengkajian BPTP Karangploso T.A. 1989/1999. BPTP Karangploso, Malang.

Hafez. 1993. Reproduction in Farm Animals. 6 th Edition Lea and Febiger. Philadelphia.

Hardjopranjoto. 1995. Ilmu Kemajiran pada Ternak Airlangga United Press. Surabaya.

Kusriningrum, R., H. Setyono., T.nurhajati., Agustono., M. Arief., A. Alarif, M. Lamid. 2001. Pengetahuan Bahan Pakan Ternak. Laboratorium Ilmu Makanan Ternak. FKH-Unair.

Mc Donald, P., R.A. Edward and J.F.G. Greenhalg. 1994. Animal Nutrition $4^{\text {th }}$ Edition. Longman. London and New York.

Partodiharjo, 1992. Ilmu Reproduksi Ternak. Mutiara Sumber Widya. Jakarta.

Toelihere, 1984. Ilmu Kemajiran Pada Ternak. IPB Press. Bogor. 